\title{
Survei Teknik-Teknik Database Design Menggunakan Metode Systematic Literature Review
}

\author{
Mohamad Ichsan Wibawa ${ }^{1, *}$, Farhan Rafif Azzufar ${ }^{2}$, Ilmi Rasyidah Firdaus ${ }^{3,}$ Muhammad Ainul Yaqin ${ }^{4}$ \\ Jurusan Teknik Informatika, Universitas Islam Negeri Maulana Malik Ibrahim, Indonesia \\ ${ }^{1} 19650102 @$ student.uin-malang.ac.id; ${ }^{2} 19650108 @$ student.uin-malang.ac.id; ${ }^{3} 19650115 @$ @ student.uin-malang.ac.id; \\ ${ }^{4}$ yaqinov@ti.uin-malang.ac.id \\ * corresponding author
}

INFO ARTIKEL

\section{Sejarah Artikel}

Diterima: 19 Juni 2021

Direvisi: 5 Juli 2021

Diterbitkan: 30 Agustus 2021

Kata Kunci

Systematic Literature Review

Database Design

Model Database

\begin{abstract}
ABSTRAK
Teknik database desain adalah segala metode yang berhubungan dengan kegiatan perancangan dalam membuat sebuah database. Dalam mendesain database, terdapat beberapa teknik yang dapat digunakan. Namun dalam penggunaanya, kerap dijumpai kurangnya kecocokan teknik dengan jenis database yang akan digunakan. Maka dari itu, tujuan dibuatnya paper ini untuk menyajikan pasangan teknik dan jenis database yang baik untuk dikombinasikan. Manfaat dari pembuatan paper ini yaitu untuk membantu para developer dalam menentukan teknik dan jenis database yang sesuai, yang nantinya akan diterapkan pada aplikasi yang dibangun. Metode yang digunakan dalam mencapai tujuan tersebut adalah meninjau Systematic Literature Review (SLR) terhadap paper-paper penelitian yang membahas tentang teknik mendesain database dari tahun 1988-2018. Hasil yang diperoleh yaitu teknik-teknik dalam mendesain database antara lain teknik normalisasi, teknik entityrelationship, dan teknik date wilson. Berdasarkan survei yang telah dilakukan, didapatkan kesimpulan pasangan teknik desain dengan jenis databasenya yang paling cocok digunakan dalam membangun aplikasi yang akan dibuat oleh developer untuk contoh kasus pembuatan database sistem informasi perpustakaan.
\end{abstract}

\section{PENDAHULUAN}

Teknik desain database merupakan cara dalam membuat rancangan database [1][2][3]. Pada saat membuat database, terdapat beberapa hal yang perlu diperhatikan untuk menunjang keberhasilan dan keefektifan suatu database. Keberhasilan dan keefektifan suatu database dapat dilihat berdasarkan kemudahan dalam pengolahan data yang baik dan terstruktur, serta sinkronisasinya terhadap jenis database yang akan digunakan. database sendiri dapat diartikan sebagai kumpulan dari sebuah fakta dalam bentuk data yang disimpan secara terstruktur dan dirancang sesuai dengan kebutuhan dari database tersebut [4]. Desain database merupakan suatu proses untuk menentukan rincian dari isi dan pengaturan data [5].

Masalah yang dirumuskan dalam paper ini terkait dengan kecocokan antara teknik dengan jenis database yang akan dibuat oleh developer. Dalam sebagian besar kasus, pasangan teknik dengan jenis database yang digunakan kurang cocok sehingga membuat developer kesulitan dalam menentukan teknik dan jenis database yang sesuai dalam membangun aplikasi yang akan dibuat. Artinya masih banyak pemilihan penggunaan teknik desain database yang kurang sesuai dengan jenis database yang akan dibuat. Perumusan masalah tersebut melatar belakangi survei teknik-teknik database desain ini. 
Salah satu cara untuk menyelesaikan permasalahan diatas dengan memberikan kajian dan daftar rekomendasi teknik-teknik desain database dalam menyelesaikan berbagai kasus dalam mendesain database. Sehingga para developer mempunyai gambaran teknik mana yang harus dipilih untuk membuat rancangan dan struktur database pada aplikasi yang akan dibuat. Sejauh ini, belum ada peneliti yang secara fokus menyajikan daftar rekomendasi teknik-teknik desain database. Oleh karena itu, urgensi dari survei yang dilakukan adalah menyajikan daftar teknikteknik yang dapat direkomendasikan kepada developer untuk menyelesaikan berbagai masalah terkait perancangan dalam mendesain database secara tepat dengan mengkombinasikan teknikteknik dan jenis database.

Survei bertujuan untuk memberikan penyajian antara teknik desain database dan jenis database yang sesuai. Kecocokan antara teknik desain database dan jenis database sangat penting untuk membuat rancangan dalam pembuatan database. Hal tersebut penting karena jika teknik desain database kurang tepat maka akan membuat developer kesulitan dalam membuat aplikasi yang dibuat, maka proses mendesain database akan lebih efisien jika terdapat kecocokan antara teknik desain dan jenis databasenya.

Survei dilakukan menggunakan metode Systematic Literature Review (SLR) yang bertujuan untuk mendapatkan kecocokan dengan membandingkan teknik-teknik mendesain database[6]. Metode yang dilakukan dimulai dari pengumpulan data primer dan sekunder, melakukan review pada paper, menentukan paper dan jurnal yang relevan membahas isu terkait. Survei terhadap teknik-teknik database desain sudah pernah dilakukan oleh peneliti sebelumnya. Berdasarkan hasil survei yang kami lakukan menghasilkan tiga teknik mendesain database yaitu teknik normalisasi data, teknik date wilson, dan teknik entity-relationship [7][8][9][10].

Solusi yang ditawarkan atas penyelesaian masalah adalah dengan membandingkan satu teknik dengan lainnya dan mencocokan teknik dengan jenis database, ditinjau dari berbagai sisi; 1) area implementasi, 2) kekurangan teknik, 3) riwayat penelitian. Kasus yang dibahas pada paper ini yaitu pembuatan desain database sistem informasi perpustakaan. Dari analisa perbandingan tersebut dapat ditarik kesimpulan teknik-teknik database desain yang tepat untuk membuat database aplikasi tersebut.

Hasil dari survei ini berupa ulasan tentang area implementasi, kekurangan teknik, riwayat penelitian masing-masing dari tiga teknik desain database yang ditemukan. Survei ini juga menyajikan rekomendasi pilihan teknik desain database untuk pembuatan aplikasi sistem informasi perpustakaan. Juga analisa dalam bentuk tabel yang akan memberikan informasi kepada pembaca tentang kecocokan antara teknik dan jenis database.

Manfaat yang diharapkan dalam paper survei ini adalah untuk menyajikan informasi kapada developer dalam menentukan teknik database dan jenis database yang sesuai. Sehingga perancangan dan pembuatan database yang dibangun pada aplikasi cocok dengan menggunakan rekomendasi pilihan yang tepat antara teknik dan jenis database. Sedangkan untuk researchers, hasil dari survei ini dapat dijadikan dasar untuk menggali teknik desain database lain atau teknik terbaru.

\section{METODE}

Systematic Literature Review (SLR) atau dalam bahasa indonesia disebut tinjauan pustaka sistematis adalah metode literature review yang mengidentifikasi, menilai, dan menginterpretasi seluruh temuan-temuan pada suatu topik penelitian, untuk menjawab pertanyaan penelitian (research question) yang telah ditetapkan sebelumnya [6]. Secara umum, tahapan melakukan SLR terdiri dari 3 bagian, yaitu planning, conducting, dan reporting. Detail dari tahapan yang dilakukan dapat dilihat seperti berikut: 


\section{Planning}

Tahapan yang dilakukan pada planning yaitu menentukan Research Question(RQ). RQ digunakan untuk menuntun proses pencarian dan analisa literatur. Analisa dari data sebagai hasil dari SLR merupakan jawaban dari RQ yang sebelumnya dibuat. RQ yang baik, yaitu yang bermanfaat dan terukur kepemahaman terhadap suatu topik penelitian. Formulasi RQ pada paper ini didasarkan pada 5 elemen yang disebut PICOC.

Tabel 1. Hasil Identifikasi PICOC

\begin{tabular}{|c|l|l|}
\hline P & Population & software, database, database design, database system, \\
\hline I & Intervention & Method, teknik, pengumpulan data, model database \\
\hline $\mathbf{C}$ & Comparison & Membandingkan teknik database \\
\hline $\mathbf{O}$ & Outcomes & Teknik database Design yang paling bagus digunakan \\
\hline $\mathbf{C}$ & Context & $\begin{array}{l}\text { Survei berdasarkan literatur yang sesuai, yaitu berupa } \\
\text { paper, jurnal, artikel, dan buku }\end{array}$ \\
\hline
\end{tabular}

Pada tabel 1. Hasil Identifikasi PICOC, dapat diketahui terdapat 5 elemen yang terdapat dalam formulasi PICOC diantaranya population, intervention, comparison, outcomes, context. Masing-masing elemen mempunyai keterangan dan isi menjelaskan detail dari PICOC tersebut berdasarkan judul yang dibahas.

Tabel 2. Hasil Perancangan RQ

\begin{tabular}{|c|c|c|}
\hline & RQ (Research Question) & \\
\hline RQ1 & $\begin{array}{l}\text { Apa saja } \\
\text { diperlukan } \\
\text { database? }\end{array}$ & $\begin{array}{l}\text { Mengidentifikasi dan menganalisa } \\
\text { komponen yang diperlukan dalam } \\
\text { mendesain database }\end{array}$ \\
\hline RQ2 & $\begin{array}{l}\text { Apa saja tahapan-tahapan } \\
\text { perancangan database design? }\end{array}$ & $\begin{array}{l}\text { Menganalisa tahapan dalam } \\
\text { merancang database }\end{array}$ \\
\hline RQ3 & $\begin{array}{l}\text { Apa saja teknik-teknik yang } \\
\text { digunakan dalam desain database? }\end{array}$ & $\begin{array}{l}\text { Mengidentifikasi teknik-teknik } \\
\text { desain database }\end{array}$ \\
\hline RQ4 & Apa saja jenis-jenis & se \\
\hline RQ5 & $\begin{array}{l}\text { gan antara } \\
\text { tabase }\end{array}$ & $\begin{array}{l}\text { andingkan dan menganalisis } \\
\text {-teknik mendesain database. }\end{array}$ \\
\hline RQ6 & $\begin{array}{l}\text { Bagaimana kecocokan antara } \\
\text { teknik dan jenis database? }\end{array}$ & $\begin{array}{l}\text { Menganalisis teknik dan jenis } \\
\text { database yang cocok }\end{array}$ \\
\hline RQ7 & $\begin{array}{l}\text { Bagaimana Implement } \\
\text { dan jenis database di } \\
\text { sistem informasi perpus }\end{array}$ & $\begin{array}{l}\text { Implementasi teknik dan jenis } \\
\text { database dalam kasus sistem } \\
\text { informasi perpustakaan }\end{array}$ \\
\hline
\end{tabular}

Pada Tabel 2. Hasil Perancangan RQ, dapat diketahui hasil perancangan RQ yang telah dibuat. Perancangan RQ pada jurnal ini terdapat $7 \mathrm{RQ}$, didalamnya terdapat Research Question dan Motivation yang menjelaskan detail dari masing-masing RQ.

\section{Conducting}

Conducting merupakan tahapan yang berisi dari pelaksanaan SLR, dimana sesuai dengan protokol SLR yang telah ditentukan. Dimulai dari penentuan kata kunci pencarian literatur yang dasarnya dari PICOC yang telah dibuat. Pemahaman terhadap persamaan dan alternatif pengganti kata kunci akan menetukan akurasi dari pencarian literatur. Langkah selanjutnya 
yaitu penentuan sumber dari pencarian literatur. Sumber literatur yang dicari berbentuk buku, jurnal, dan conference proceedings. Tahun publikasi sumber literatur mulau dari 1890 sampai 2018. Kata kunci pencarian sumber literatur yaitu :

("Database Design" OR “Technique Database Design")

AND

("Systematic Literature Review" OR "SLR" OR "Data Storage" OR "Analisis Data") Literature sources dalam proses pencarian literatur berasal dari digital library seperti Google Scholar, Science Direct, SpringerLink, Scopus, Researcher, dan IEEE Xplore.

\section{Jurnal yang Paling Signifikan}

Tabel 3. Hasil Analisis Jurnal Berdasarkan Q Category

\begin{tabular}{|c|c|c|}
\hline No & Jounal Publications & $Q$ category \\
\hline 1 & The Duality of database Structures and Design Techniques & Q1 in techniques \\
\hline 2 & Database Design strategies & Q1 in database \\
\hline 3 & Database Design techique & Q1 in techniques \\
\hline 4 & $\begin{array}{l}\text { Database Design: a Survei of Logical and Physical Design } \\
\text { Techniques. }\end{array}$ & Q1 in techniques \\
\hline 5 & Knowledge-Based Approaches to Database Design & Q1 in database \\
\hline 6 & $\begin{array}{l}\text { Assessment Techniques, Database Design and Software } \\
\text { Facilities for Thermodynamics and Diffusion. }\end{array}$ & Q1 in techniques \\
\hline 7 & $\begin{array}{l}\text { Physical Database Design Techniques to Improve } \\
\text { Database Performance }\end{array}$ & Q1 in techniques \\
\hline 8 & $\begin{array}{l}\text { Modeling and Teaching Techniques for Conceptual and } \\
\text { Logical Relational Database Design }\end{array}$ & Q1 in design \\
\hline 9 & Advance Object Database Design Techniques & Q1 in database \\
\hline 10 & An Ontology-based Expert System for Database Design & Q1 in database \\
\hline 11 & $\begin{array}{l}\text { The Methodology of Database Design in Organization } \\
\text { Management Systems }\end{array}$ & Q1 in design \\
\hline 12 & $\begin{array}{l}\text { Integrating Vertical and Horizontal Partitioning into } \\
\text { Automated Physical Database Design }\end{array}$ & Q1 in database \\
\hline 13 & Introduction to Physical Database Design & Q1 in design \\
\hline 14 & A Database Approach to Engineering Design by Selection & Q1 in database \\
\hline 15 & $\begin{array}{l}\text { Building a Database for Product Design Knowledge } \\
\text { Retrieval_A Case study in Robotic Design Database }\end{array}$ & Q1 in design \\
\hline 16 & A Database Design Technique for Finite Element Analysis & Q1 in database \\
\hline 17 & A Meta-advisor Repository for Database Physical Design & Q1 in database \\
\hline 18 & How to Design and Use a Research Database & Q1 in design \\
\hline 19 & $\begin{array}{l}\text { The Database Architecture Design of the Satellite } \\
\text { Simulation Platform }\end{array}$ & Q1 in database \\
\hline
\end{tabular}

Berdasarkan Tabel 3. Hasil Analisis Jurnal Berdasarkan Q Category, hasil identifikasi dan analisis, tabel diatas menunjukkan jurnal yang paling signifikan yang telah dikumpulkan. Kemudian jurnal tersebut disaring sehingga mendapatkan jurnal yang paling signifikan berdasarkan Q category. Terdapat tiga jurnal dan buku yang paling signifikan yaitu :

1) The Duality of database Structures and Design Techniques, 
2) Database Design Strategies, dan

3) Database Design Techique.

Referensi paper yang telah dikumpulkan berdasarkan tahun diterbitkannya dari tahun 1980 sampai tahun 2016.

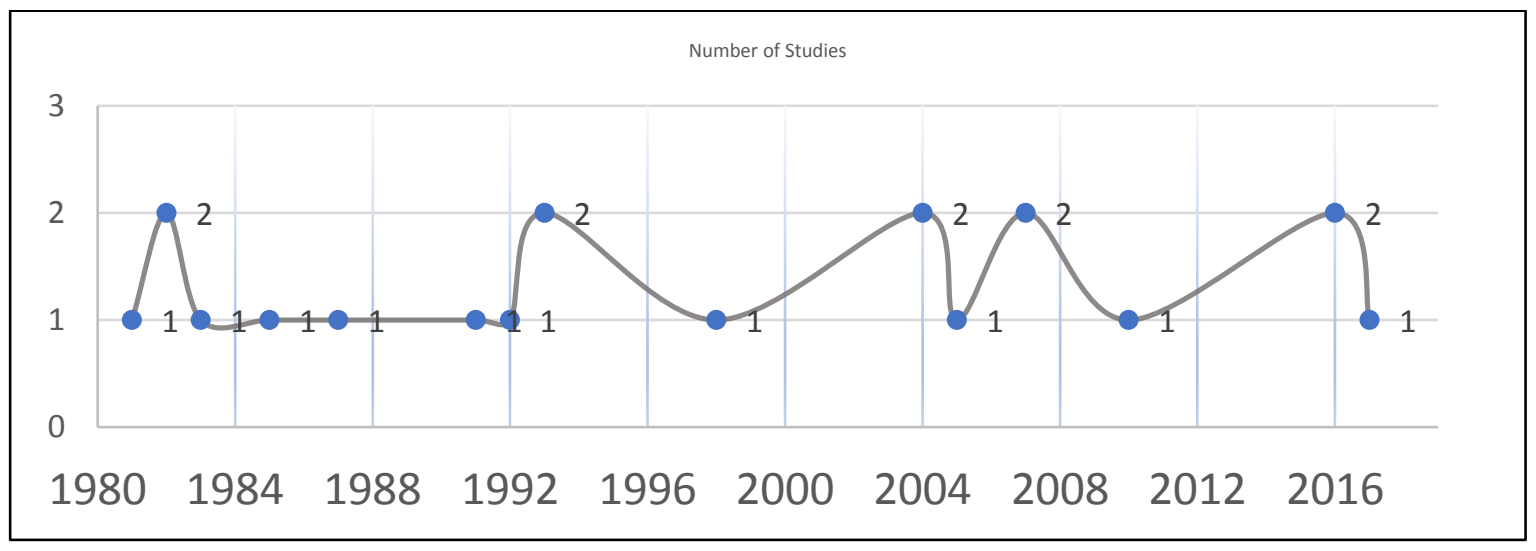

Gambar 1. Grafik analisis jurnal berdasarkan tahun publikasi

Berdasarkan Gambar 1. Grafik analisis jurnal berdasarkan tahun publikasi, dapat diketahui publikasi dari referensi jurnal yang digunakan pada pembuatan jurnal ini. Tahun publikasi jurnal referensi dimulai dari tahun 1980 hingga tahun 2018.

\section{Peneliti yang Paling Aktif}

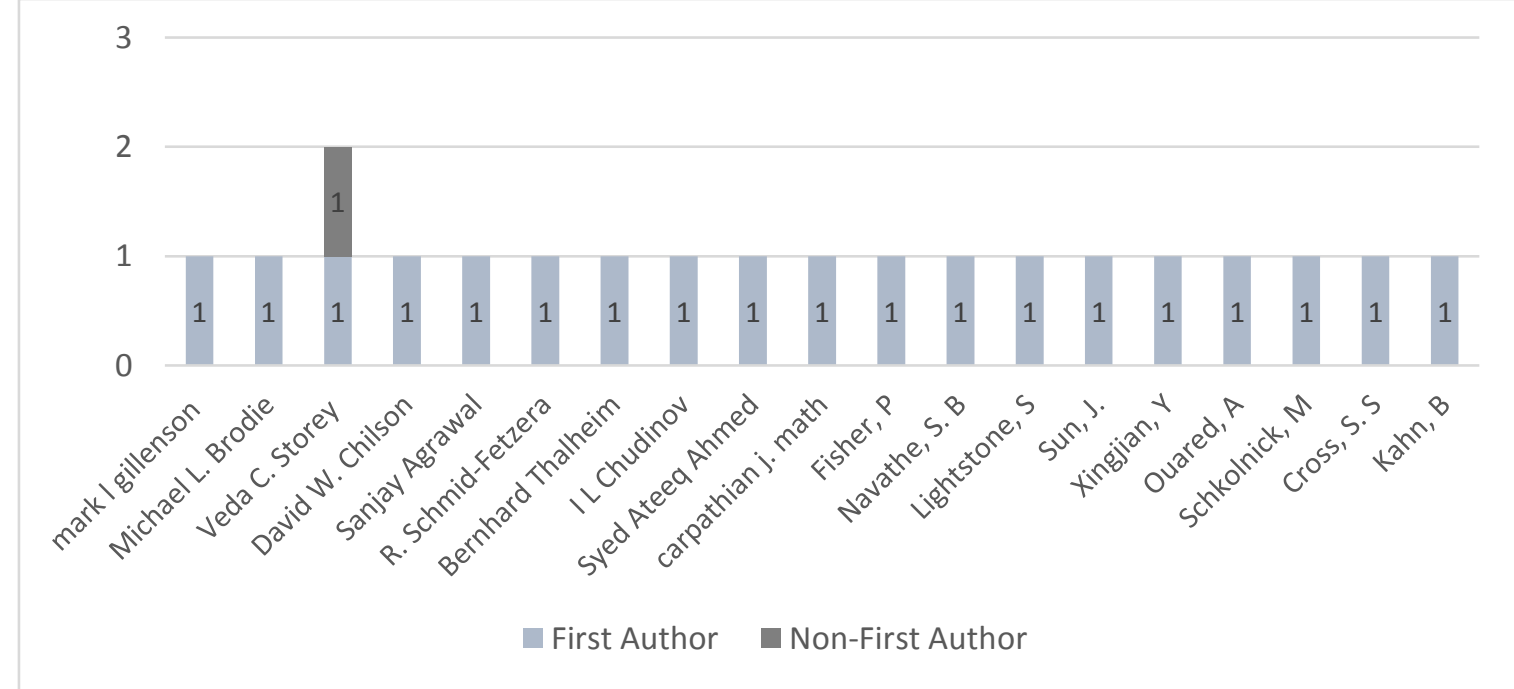

Gambar 2. Grafik analisis peneliti yang paling aktif

Berdasarkan Gambar 2. Grafik analisis peneliti yang paling aktif, terdapat peneliti yang paling berpengaruh pada paper ini. Peneliti terdiri dari peneliti pertama dan bukan peneliti pertama. Dari gambar 2. dapat disimpulkan bahwa Veda C. Storey merupakan peneliti yang paling aktif membahas tentang teknik mendesain database dibandingkan peneliti lainnya. Maka dari itu kami mengambil sebagian besar sumber penelitian kami dari jurnal atau paper milik Veda C. Storey. Selain itu, jurnal atau paper yang berpengaruh besar pada paper ini adalah jurnal milik Mark L. Gillenson. 


\section{Topik yang Dipilih Peneliti}

Tabel 4. Hasil Analisis Jurnal Berdasarkan Kategori

\begin{tabular}{|c|c|c|c|c|}
\hline \multirow[t]{2}{*}{ Publications } & \multicolumn{4}{|c|}{ Topics } \\
\hline & $\begin{array}{l}\text { Analy } \\
\text { sis }\end{array}$ & $\begin{array}{l}\text { Clusteri } \\
\quad n g\end{array}$ & $\begin{array}{l}\text { Techn } \\
\text { ique }\end{array}$ & $\begin{array}{l}\text { Classifi } \\
\text { cation }\end{array}$ \\
\hline Querry Processing in database system & & & $\checkmark$ & \\
\hline $\begin{array}{l}\text { A database Design technique for finite } \\
\text { element analysis }\end{array}$ & $\checkmark$ & $\checkmark$ & $\checkmark$ & \\
\hline $\begin{array}{l}\text { A Meta-advisor Repository for database } \\
\text { Physical Design }\end{array}$ & $\checkmark$ & & & \\
\hline Advanced Object Database Design technique & $\checkmark$ & $\checkmark$ & $\checkmark$ & \\
\hline $\begin{array}{l}\text { Integrating Vertical and Horizontal } \\
\text { Partitioning Into Automated Physical } \\
\text { database Design }\end{array}$ & $\checkmark$ & $\checkmark$ & & \\
\hline $\begin{array}{l}\text { Assessment Technique, Database Design and } \\
\text { Software Facilities for Thermodynamics and } \\
\text { Diffusion }\end{array}$ & $\checkmark$ & $\checkmark$ & & \\
\hline $\begin{array}{l}\text { Database Design : A Survei of Logical and } \\
\text { Physical Design Technique }\end{array}$ & & $\checkmark$ & & \\
\hline Database Design Technique & $\checkmark$ & $\checkmark$ & $\checkmark$ & \\
\hline Database Management : Concept and Design & $\checkmark$ & $\checkmark$ & & \\
\hline $\begin{array}{l}\text { Desain Database Sistem Informasi Akademik } \\
\text { Pada Lembaga Pendidikan Tinggi }\end{array}$ & $\checkmark$ & & & $\checkmark$ \\
\hline $\begin{array}{l}\text { Design and Analysis of a Relational Database } \\
\text { for Behavioral Experiments Data Processing }\end{array}$ & $\checkmark$ & $\checkmark$ & & \\
\hline $\begin{array}{l}\text { The Duality Of database Structures and } \\
\text { Design Technique }\end{array}$ & $\checkmark$ & & $\checkmark$ & \\
\hline How to Design and Use a Research Database & $\checkmark$ & & & \\
\hline Introduction to Physical Database Design & $\checkmark$ & $\checkmark$ & & \\
\hline $\begin{array}{l}\text { Desain Model Database Layanan Panti } \\
\text { Werdha dengan Menerapkan Metode } \\
\text { Database Life Cycle }\end{array}$ & $\checkmark$ & & & \\
\hline $\begin{array}{l}\text { Knowledge-Base Approaches to Database } \\
\text { Design }\end{array}$ & $\checkmark$ & $\checkmark$ & & \\
\hline $\begin{array}{l}\text { LDDM - A Structured Logical Database } \\
\text { Design Methodology }\end{array}$ & $\checkmark$ & $\checkmark$ & & \\
\hline $\begin{array}{l}\text { Modeling and Teaching Techniques for } \\
\text { Conceptual and Logical Relational Database } \\
\text { Design }\end{array}$ & $\checkmark$ & $\checkmark$ & $\checkmark$ & \\
\hline $\begin{array}{l}\text { Perancangan Basis Data Perpustakaan } \\
\text { Sekolah Dengan Menerapkan Model Data } \\
\text { Relasional }\end{array}$ & $\checkmark$ & & $\checkmark$ & \\
\hline $\begin{array}{l}\text { Perancangan Basis Data Perusahaan } \\
\text { Distribusi }\end{array}$ & $\checkmark$ & & $\checkmark$ & \\
\hline Physical Database Design Techniques & $\checkmark$ & & & \\
\hline $\begin{array}{l}\text { Physical Database Design Techniques to } \\
\text { Improve Database Performance }\end{array}$ & $\checkmark$ & $\checkmark$ & & \\
\hline
\end{tabular}




\begin{tabular}{|c|c|c|c|}
\hline $\begin{array}{l}\text { Database Design Based on The Higher-Order } \\
\text { Entity-Relationship Model with The Tool } \\
\text { Boxes }\end{array}$ & $\checkmark$ & $\checkmark$ & $\checkmark$ \\
\hline $\begin{array}{l}\text { Assessment Techniques, Database Design } \\
\text { and Software Facilities for Thermodynamics } \\
\text { and Diffusion }\end{array}$ & $\checkmark$ & $\checkmark$ & \\
\hline $\begin{array}{l}\text { An Ontology-Based Expert System for } \\
\text { Database Design }\end{array}$ & $\checkmark$ & & $\checkmark$ \\
\hline $\begin{array}{l}\text { The Database Architecture Design of The } \\
\text { Satellite Simulation Platform }\end{array}$ & $\checkmark$ & & \\
\hline
\end{tabular}

Bedasarkan Tabel 4. Hasil Analisis Jurnal Berdasarkan Kategori, merupakan himpunan dari jurnal-jurnal yang telah disaring berdasarkan jurnal yang paling relevan dengan paper ini. Jurnal tersebut terbagi ke dalam beberapa kategori yaitu analysis, clustering, technique, dan classification.

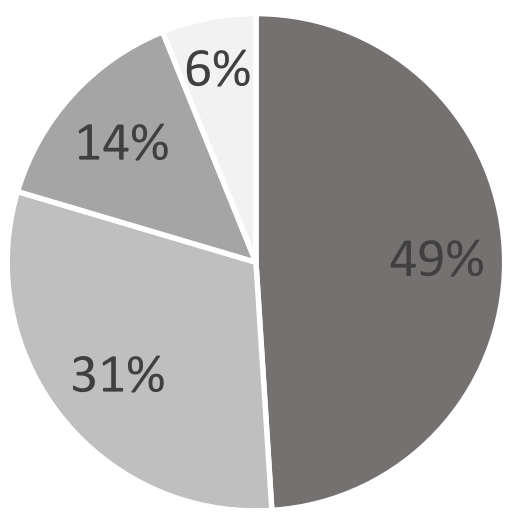

- Analysis - Clustering $\quad$ Technique Classification

Gambar 3 Grafik hasil analisis jurnal berdasarkan kategori

Diatas juga terdapat diagram presentase dari masing-masing kategori Gambar 3 Grafik hasil analisis jurnal berdasarkan kategori, Dari data diatas dapat dikatakan bahwa jurnal yang dikumpulkan $49 \%$ mengandung unsur analisis, $31 \%$ mengandung unsur clustering, $14 \%$ mengandung unsur technique, $6 \%$ mengandung unsur classification.

\section{Komponen Database}

Tabel 5. Komponen-komponen database

\begin{tabular}{|l|l|}
\hline Komponen basis data & Komponen ERD \\
\hline $\begin{array}{l}\text { Hardware yaitu komponen } \\
\text { pendukung operasi dalam operasi } \\
\text { pengolah data contoh nya seperti } \\
\text { memori, disk, CPU, terminal dan lain } \\
\text { sebagai nya. }\end{array}$ & yang mempresentasikan data. \\
\hline
\end{tabular}




\begin{tabular}{|c|c|c|}
\hline $\begin{array}{l}\text { Perangkat lunak atau software dalam } \\
\text { pengelola basis data yaitu } S Q L, M S- \\
\text { Access, } S Q L, \text { Oracle. }\end{array}$ & \multirow[t]{3}{*}{ Attribute } & \multirow{3}{*}{ 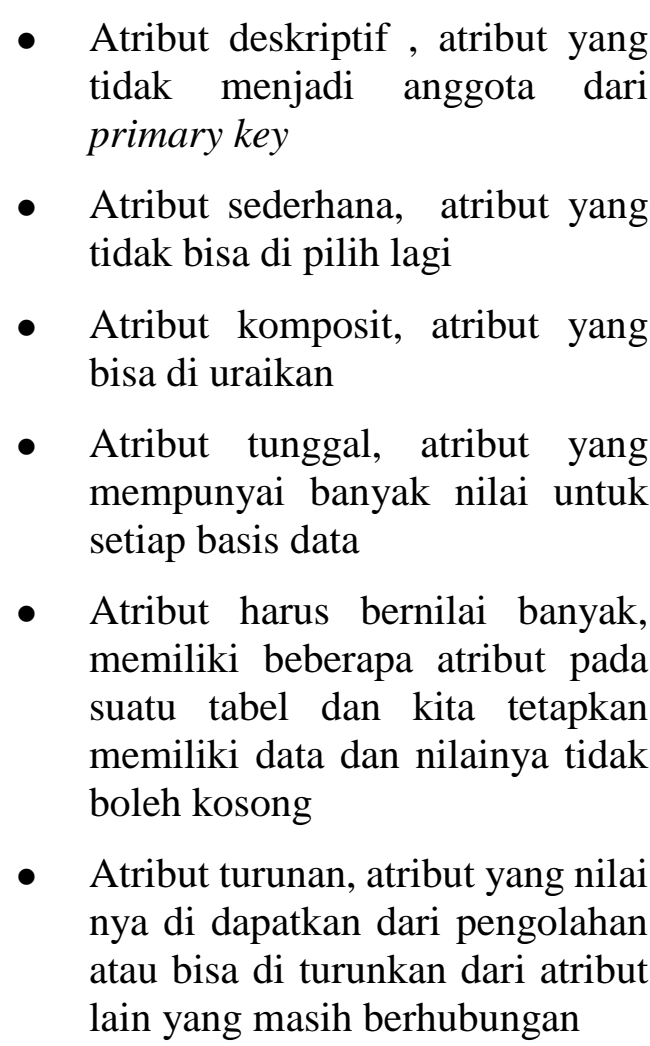 } \\
\hline $\begin{array}{l}\text { Perangkat lunak atau software untuk } \\
\text { sistem operasi, yaitu windows } \\
2000 / X P \text {, windows } 9 x \text {, Unix, Linux. }\end{array}$ & & \\
\hline $\begin{array}{l}\text { Perangkat lunak atau software } \\
\text { program aplikasi yaitu Delpi, Visual } \\
\text { Foxpro, visual basic. }\end{array}$ & & \\
\hline $\begin{array}{l}\text { Data base komponen yang di } \\
\text { pelihara, di perlukan dan di kelola } \\
\text { oleh sistem pada basis data. }\end{array}$ & Relasi & $\begin{array}{l}\text { - One - to - one } \\
\text { - One - to - many } \\
\text { - Many - to - many }\end{array}$ \\
\hline
\end{tabular}

Dari data Tabel 5. Komponen-komponen database, tedapat komponen-komponen pada database yang diperlukan dalam merangcang database. Komponen-komponen tersebut terdiri dari komponen basis data dan komponen ERD. Komponen basis data meliputi perangkat lunak dan perangkat keras yang diperlukan dalam mendesain database. Sedangkan komponen ERD, terdiri dari entity, atribut, dan relasi.

Teknik-teknik Database Design

Tabel 6. Teknik-teknik database design

\begin{tabular}{|c|c|c|c|c|}
\hline No. & Teknik & Gambar & $\mathrm{S}$ & Penjelasan \\
\hline 1. & $\begin{array}{l}\text { The Data } \\
\text { Normalization } \\
\text { technique }\end{array}$ & Gambar 4 & $\begin{array}{l}\text { [7], [8], } \\
{[9],[10],} \\
{[11],[12]}\end{array}$ & $\begin{array}{lrr}\text { Teknik } & \text { normalisasi } & \text { data } \\
\text { merupakan } & \text { teknik dalam } \\
\text { mendesain database dengan } & \text { dattom- } \\
\text { pendekatan } & \text { bottom } \\
\text { Pendekatan bottom-up merupakan } \\
\text { cara pengelompokan data, dimana } \\
\text { data tesebut dibuat menjadi } \\
\text { beberapa tabel yang berisi data } \\
\text { spesifik. }\end{array}$ \\
\hline
\end{tabular}




\begin{tabular}{|l|l|l|l|l|}
\hline 2. & $\begin{array}{l}\text { The Date } \\
\text { Wilson } \\
\text { technique }\end{array}$ & Gambar 5 & {$[7]$} & $\begin{array}{l}\text { Teknik Date Wilson merupakan } \\
\text { teknik untuk mendesain database } \\
\text { dengan cara mengansumsikan } \\
\text { entitas dan mengidentifikasi } \\
\text { keunikan dari data, sehingga akan } \\
\text { lebih mudah dalam mendesain } \\
\text { database. }\end{array}$ \\
\hline 3. & $\begin{array}{l}\text { The entity } \\
\text { Relationship } \\
\text { technique }\end{array}$ & Gambar 6 & $\begin{array}{l}{[7],[9],} \\
{[12],[13],} \\
{[32]}\end{array}$ & $\begin{array}{l}\text { Teknik entity relationship } \\
\text { merupakan teknik dalam } \\
\text { mendesain database, dimana } \\
\text { tahapan awalnya menganalisis } \\
\text { data, lalu membuat pembagian } \\
\text { atribut dan entitas, lalu atribut } \\
\text { tersebut dimasukan ke dalam } \\
\text { entitas yang sesuai. }\end{array}$ \\
\hline
\end{tabular}

Berdasarkan Tabel 6. Teknik-teknik database design, dapat diketahui teknik database beserta gambar dan penjelasan yang ada pada tabel. Pada tabel 6 juga terdapat referensi jurnal yang diambil. Teknik-teknik yang ditemukan dari referensi jurnal yang kami identifikasi diantaranya The Data Normalization technique, The Date Wilson technique, The entity Relationship technique.

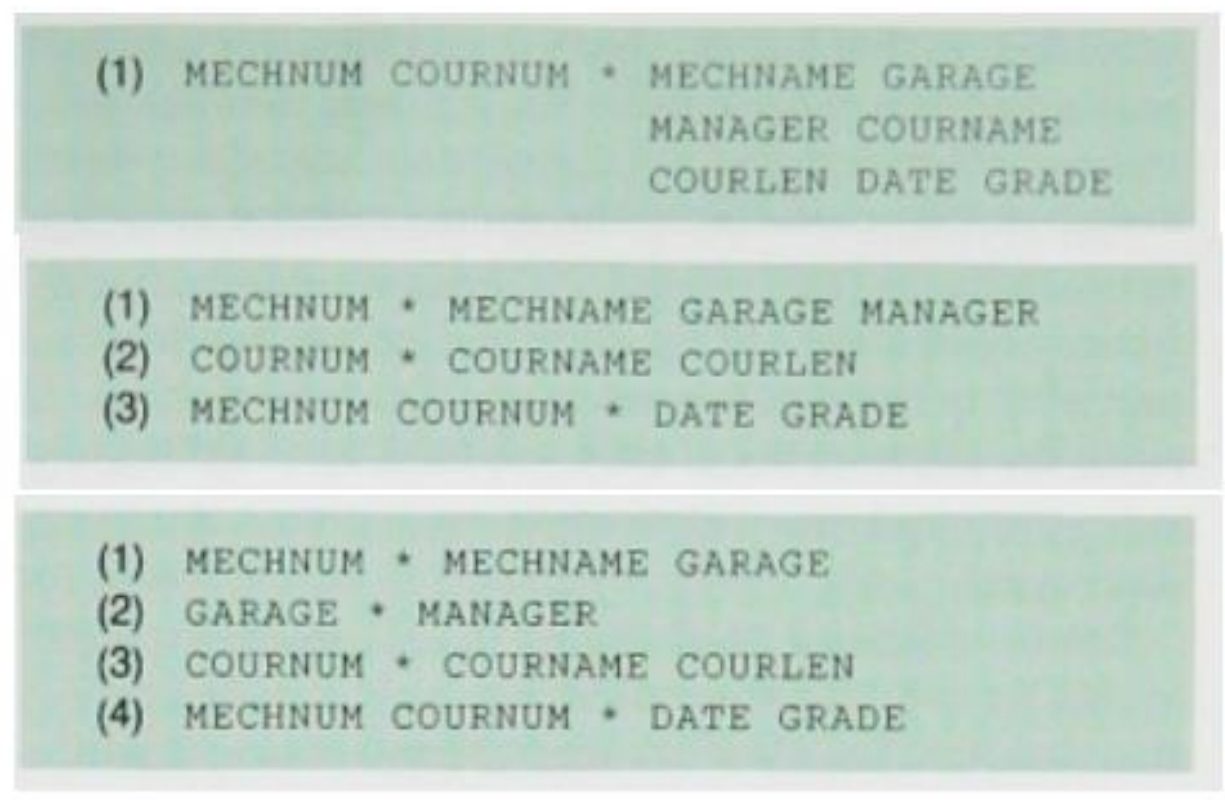

Gambar 4. Desain database Menggunakan Teknik Normalisasi

Berdasarkan Gambar 4. Desain database Menggunakan Teknik Normalisasi, merupakan contoh desain database dari teknik normalisasi data. Terdapat tiga tahap normalisasi yang dilakukan. Tahap pertama disebut tahap 1NF, tahap kedua dinamakan tahap $2 \mathrm{NF}$, dan tahap ketiga dinamakan 3NF. 
(1) MEchnum -

(2) GARAGE *

(3) COURNUM *

(1) MECHNUM * MECHNAME

(2) GARAGE * MANAGER

(3) COURNUM * COURNAME COURLEN

(1) MECHNUM - MECHNAME GARAgE

(2) GARAGE * MANAGER

(3) COURNUM * COURNAME COURLEN

(1) MECHNUM * MECHNAME GARAGE

(2) GARAGE * MANAGER

(3) COURNUM * COURNAME COURLEN

(4) MECHNUM COURNUM * DATE GRADE

Gambar 5. Desain database Mengggunakan Teknik Date Wilson

Berdasarkan Gambar 5. Desain database Mengggunakan Teknik Date Wilson, merupakan contoh desain database dari teknik date wilson Terdapat empat tahap yang dilakukan. Tahap pertama yaitu membangun tabel dasar, tahap kedua yaitu menambahkan atribut, dan tahap ketiga yaitu menambahkan foreign key untuk relasi one-to-many dan tahap keempat yaitu menambahkan relasi many-to-many.

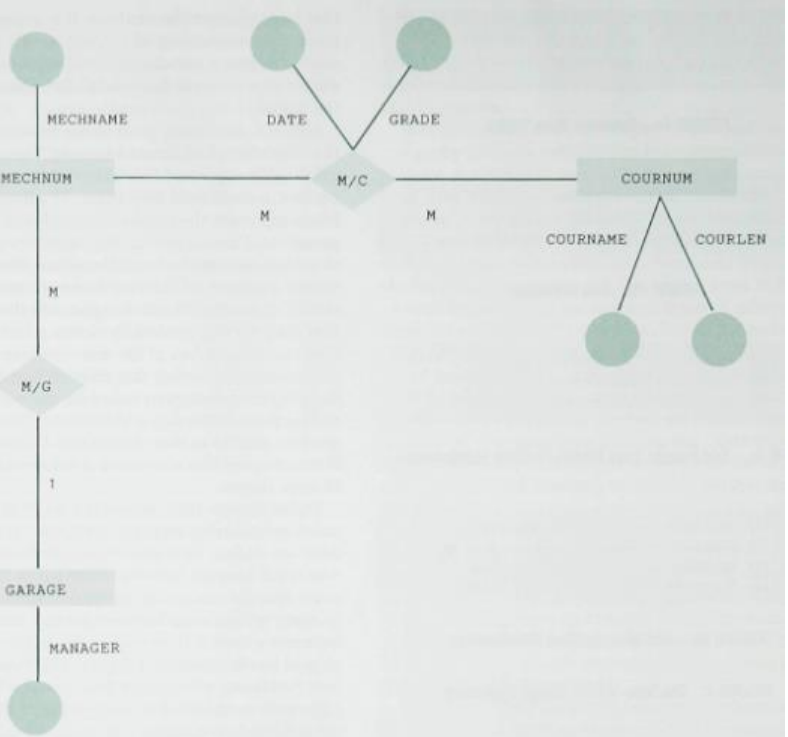

Gambar 6. Desain database Menggunakan Teknik Entity-relationship

Berdasarkan Gambar 6. Desain database Menggunakan Teknik Entity-relationship, merupakan contoh desain database dengan menggunakan Teknik Entity-relationship. Dimana tahapan awalnya menganalisis data, lalu membuat pembagian atribut dan entitas, lalu atribut tersebut dimasukkan ke dalam entitas yang sesuai. 
Jenis-jenis Database

\begin{tabular}{|c|c|c|c|c|}
\hline No & $\begin{array}{c}\text { Jenis } \\
\text { Database }\end{array}$ & $\begin{array}{l}\text { Contoh } \\
\text { Gambar }\end{array}$ & $\mathbf{S}$ & Penjelasan \\
\hline 1. & $\begin{array}{l}\text { Cloud } \\
\text { database }\end{array}$ & $\begin{array}{l}\text { Gambar } \\
7\end{array}$ & $\begin{array}{l}{[14],} \\
{[15],} \\
{[16]}\end{array}$ & $\begin{array}{l}\text { - Diakses oleh client melalui } \\
\text { internetdari layanan cloud } \\
\text { database penyedia } \\
\text { - Ketika client membutukhan data, } \\
\text { maka layanan cloud database } \\
\text { akan mengirimkan data yang } \\
\text { sebelumnya telah disimpan oleh } \\
\text { client } \\
\text { - Diimplementasikan } \\
\text { menggunakan cloud computing } \\
\text { - Cloud database banyak } \\
\text { digunakan sebagai servis }\end{array}$ \\
\hline 2. & $\begin{array}{l}\text { Key-Value } \\
\text { database }\end{array}$ & $\begin{array}{l}\text { Gambar } \\
8\end{array}$ & $\begin{array}{l}{[1],[17],} \\
{[18],[19]}\end{array}$ & $\begin{array}{l}\text { - Informasi dalam key-value } \\
\text { database terdiri dari dua } \\
\text { komponen, yaitu komponen yang } \\
\text { menggambarkan key-string dan } \\
\text { value sebenarnya. } \\
\text { - Jumlah key dapat terdiri dari } \\
\text { sekelompok atribut yang dinamis } \\
\text { pada key-value database selama } \\
\text { penyimpanan data } \\
\text { - Data yang disimpan diurutkan } \\
\text { berdasarkan abjad } \\
\text { - Dapat melakukan CRUD } \\
\text { - Semua relasi antar data disimpan } \\
\text { dalam sebuah aplication code }\end{array}$ \\
\hline 3. & $\begin{array}{l}\text { Document- } \\
\text { Storage } \\
\text { database }\end{array}$ & $\begin{array}{l}\text { Gambar } \\
9\end{array}$ & $\begin{array}{l}\text { [1], [17], } \\
{[18],[19]}\end{array}$ & $\begin{array}{l}\text { - Dokumen dialamatkan dalam } \\
\text { database menggunakan key unik } \\
\text { yang merepresentasikan } \\
\text { dokumen tersebut. } \\
\text { - Ada beberapa variasi untuk } \\
\text { mengatur data (collection, tags, } \\
\text { non- visible metadata dan } \\
\text { directory hierarchies) } \\
\text { - Untuk mengambil dokumen } \\
\text { menggunakan pencarian key- } \\
\text { value }\end{array}$ \\
\hline 4. & $\begin{array}{l}\text { Columnar } \\
\text { database }\end{array}$ & $\begin{array}{l}\text { Gambar } \\
10\end{array}$ & $\begin{array}{l}{[17],} \\
{[19]}\end{array}$ & $\begin{array}{l}\text { - Database ini juga dikenal sebagai } \\
\text { database berorientasi kolom } \\
\text { - Ada dua jenis database columnar } \\
\text { yaitu Wide-Column data storage } \\
\text { dan column oriented database } \\
\text { - Kecepatan database ini lebih } \\
\text { cepat dari based database dalam }\end{array}$ \\
\hline
\end{tabular}




\begin{tabular}{|c|c|c|c|c|}
\hline & & & & $\begin{array}{l}\text { proses query } \\
\text { - Penyimpanan dilakukan tiap } \\
\text { kolom }\end{array}$ \\
\hline 5. & $\begin{array}{l}\text { Graph } \\
\text { database }\end{array}$ & $\begin{array}{l}\text { Gambar } \\
11\end{array}$ & $\begin{array}{l}{[17],} \\
{[19],} \\
{[20],[21]}\end{array}$ & $\begin{array}{l}\text { - Memiliki kinerja yang cukup } \\
\text { tinggi jika dilihat dari contact } \\
\text { deep transversal-nya } \\
\text { - Fungsi dari database ini untuk } \\
\text { menentukan jalur terpendek } \\
\text { - Graph database dapat diberi } \\
\text { skala, namun ketika dilakukan } \\
\text { pemberian skala maka } \\
\text { kompleksitas meningkat. }\end{array}$ \\
\hline 6. & $\begin{array}{l}\text { Embedded } \\
\text { database }\end{array}$ & $\begin{array}{l}\text { Gambar } \\
12\end{array}$ & [22] & $\begin{array}{l}\text { - Dapat diimplementasikan } \\
\text { sebagian dalam dua device, } \\
\text { software maupun hardware } \\
\text { - Bagian dari sistem embedded } \\
\text { - Dapat diimplementasikan pada } \\
\text { aplikasi front-end } \\
\text { - Mempunyai batasan memori, } \\
\text { waktu, dan temporal. }\end{array}$ \\
\hline 7. & $\begin{array}{l}\text { Object- } \\
\text { Oriented } \\
\text { database }\end{array}$ & $\begin{array}{l}\text { Gambar } \\
13\end{array}$ & $\begin{array}{l}{[23],} \\
{[24],} \\
{[25]}\end{array}$ & $\begin{array}{l}\text { - Sistem database ini diadopsi } \\
\text { salah satu dari dua pendekatan } \\
\text { berbeda dari penggguna } \\
\text { interface. } \\
\text { - database ini merupakan } \\
\text { gabungan konsep antara } \\
\text { pemrograman berorientasi object } \\
\text { dengan database sebagai media } \\
\text { penyimpanan datanya. } \\
\text { - Media penyimpna datanya } \\
\text { berbentuk class-class, sehingga } \\
\text { dalam hal ini masih berhubungan } \\
\text { erat dengan E-R Model. }\end{array}$ \\
\hline 8. & $\begin{array}{l}\text { Centralized } \\
\text { database }\end{array}$ & $\begin{array}{l}\text { Gambar } \\
14\end{array}$ & $\begin{array}{l}{[26],} \\
{[27]}\end{array}$ & $\begin{array}{l}\text { - Menampung seluruh data } \\
\text { kelompok pada komputer pusat } \\
\text { seperti server atau mainframe. } \\
\text { - Setiap anggota kelompok dapat } \\
\text { mengakses data melalui } \\
\text { perangkat masing-masing. }\end{array}$ \\
\hline 9. & $\begin{array}{l}\text { Distributed } \\
\text { database }\end{array}$ & $\begin{array}{l}\text { Gambar } \\
15\end{array}$ & [26] & $\begin{array}{l}\text { - Database ini menyimpan data } \\
\text { pada suatu perangkat, dimana } \\
\text { data disimpan pada lokasi yang } \\
\text { berbeda. } \\
\text { - Data ini dapat disimpan pada } \\
\text { berbagai perangkat dalam satu } \\
\text { lokasi fisik yang sama maupun } \\
\text { lokasi fisik berbeda dengan syarat } \\
\text { saling terhubung dalam satu }\end{array}$ \\
\hline
\end{tabular}




\begin{tabular}{|c|c|c|c|c|}
\hline & & & & jaringan. \\
\hline 10 . & $\begin{array}{l}\text { Hierarchical } \\
\text { database }\end{array}$ & $\begin{array}{l}\text { Gambar } \\
16\end{array}$ & [24] & $\begin{array}{l}\text { - Database hierarki merupakan } \\
\text { database dengan model pohon, } \\
\text { hubungan antara field } \\
\text { digambarkan seperti struktur } \\
\text { pohon yang di dalamnya terdapat } \\
\text { hubungan field tersebut (parent } \\
\text { child). } \\
\text { - field paling atas disebut sebagai } \\
\text { akar(root) dan hubungan antara } \\
\text { field tersebut dapat berjenis } \\
\text { hubungan one-to-one, one-to- } \\
\text { many, dan many-to-many. }\end{array}$ \\
\hline 11. & $\begin{array}{l}\text { End-user } \\
\text { database. }\end{array}$ & $\begin{array}{l}\text { Gambar } \\
17\end{array}$ & [28] & $\begin{array}{l}\text { - Database ini terdiri dari berbagai } \\
\text { file data yang dikembangkan oleh } \\
\text { end-user di workstation mereka. } \\
\text { - Database ini mempunyai } \\
\text { beberapa contoh dalam } \\
\text { implementasinya, diantaranya } \\
\text { koleksi terhadap dokumen, } \\
\text { spreadsheet, download file, dan } \\
\text { word processing. }\end{array}$ \\
\hline 12. & $\begin{array}{l}\text { Operational } \\
\text { database. }\end{array}$ & $\begin{array}{l}\text { Gambar } \\
18\end{array}$ & [29] & $\begin{array}{l}\text { - Operational database adalah } \\
\text { database yang biasanya lebih } \\
\text { sering digunakan untuk } \\
\text { penggunaan database dinamis } \\
\text { secara realtime, database ini juga } \\
\text { bisa disebut OLTP (On Line } \\
\text { Transactional Processing). }\end{array}$ \\
\hline 13. & $\begin{array}{l}\text { Relational } \\
\text { database. }\end{array}$ & $\begin{array}{l}\text { Gambar } \\
19\end{array}$ & $\begin{array}{l}{[1],[17],} \\
{[19],} \\
{[24],} \\
{[30],} \\
{[31]}\end{array}$ & $\begin{array}{l}\text { - Database relasional adalah jenis } \\
\text { database yang menyimpan dan } \\
\text { menyediakan akses ke titik data } \\
\text { yang terkait satu sama lain. } \\
\text { - Database relasional didasarkan } \\
\text { pada model relasional, cara yang } \\
\text { intuitif dan langsung untuk } \\
\text { merepresentasikan data dalam } \\
\text { tabel. } \\
\text { - Dalam database relasional, setiap } \\
\text { baris dalam tabel adalah record } \\
\text { dengan ID unik yang disebut key. } \\
\text { - Kolom tabel menyimpan atribut } \\
\text { data, dan setiap record biasanya } \\
\text { memiliki nilai untuk setiap } \\
\text { atribut, sehingga memudahkan } \\
\text { untuk membangun hubungan di } \\
\text { antara titik data. }\end{array}$ \\
\hline
\end{tabular}


Berdasarkan Tabel 7. Jenis-jenis database, dapat diketahui jenis database yang didalamnya memuai informasi berupa gambar, referensi jurnal, dan penjelasan. Jenis database yang di identifikasi dari referensi jurnal terdapat 13 jenis database yaitu Cloud database, KeyValue database, Document- Storage database, Columnar database, Embedded database, Graph database, Object- Oriented database, Centralized database, Distributed database, Hierarchical database, End-user database, Operational database, Relational database.

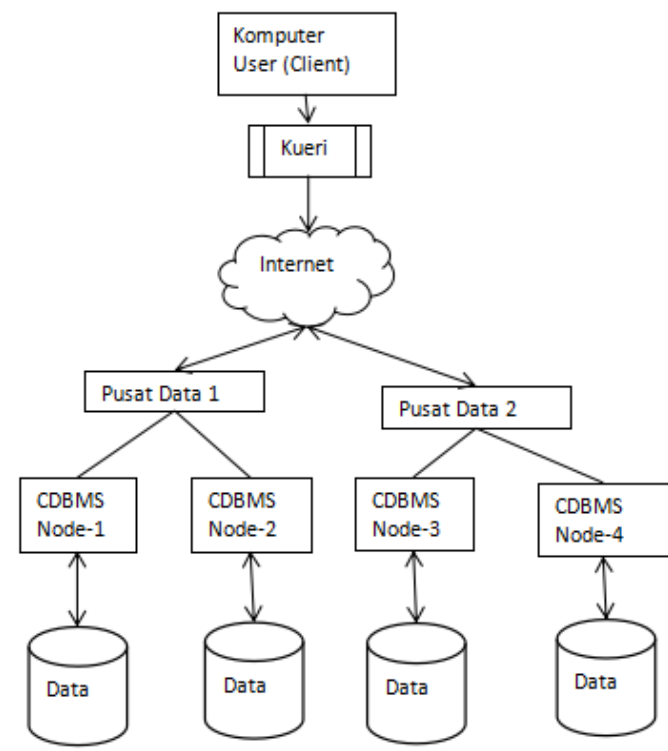

Gambar 7. Cloud database

Berdasarkan Gambar 7. Cloud database, merupakan contoh desain cloud database. Pada komputer client dikirim kueri melalui internet yang kemudian dikirm kepusat data melalui CDBMS Node masing-masing sehingga data dapat tersimpan.

\begin{tabular}{|c|c|}
\hline \multicolumn{2}{|c|}{ BANK DATABASE } \\
\hline Key & Value \\
\hline 1 & ID: 1 \\
& $\begin{array}{c}\text { Joining Date: } 15-J u l y-1985 \\
\text { Designation: Cashier }\end{array}$ \\
\hline 2 & ID:2 \\
& $\begin{array}{c}\text { Joining Date: 19-March-1982 } \\
\text { Designation: Manager }\end{array}$ \\
3 & ID:3 \\
& $\begin{array}{c}\text { Joining Date: 4-April-1988 } \\
\text { Designation: Front Desk Officer }\end{array}$ \\
\hline
\end{tabular}

Gambar 8. Key-value database

Berdasarkan Gambar 8. Key-value database, merupakan contoh desain Key-value database. Terdapat bank database yang terdiri dari key yang mempunyai masing-masing nilai dan didalamnya terdapat value masing-masing sesuai dengan key. 


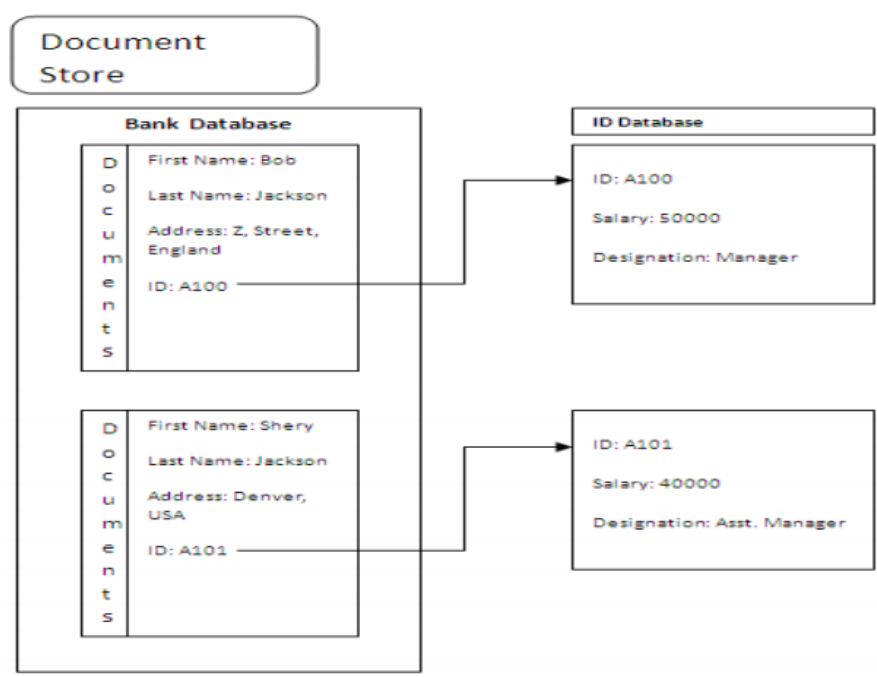

Gambar 9. Document-Storage database

Berdasarkan Gambar 9. Document-Storage database, merupakan contoh desain DocumentStorage database. Terdapat Bank database yang didalamnya terdapat masing masing id database yang menandakan sebagai spesifik dari database.

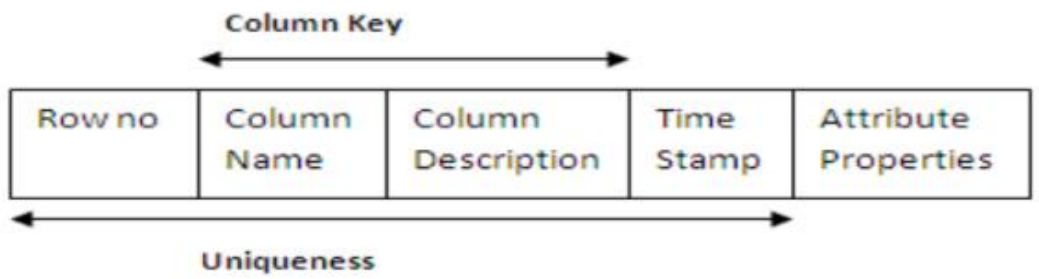

Gambar 10. Columnar database

Berdasarkan Gambar 10. Columnar database, merupakan desain Columnar database. terdapat row no, column name, column description, time stamp dan attribute properties. Pada row no, column name, column description, dan time stamp merupakan uniqueness sedangkan column name dan column description merupakan column key.

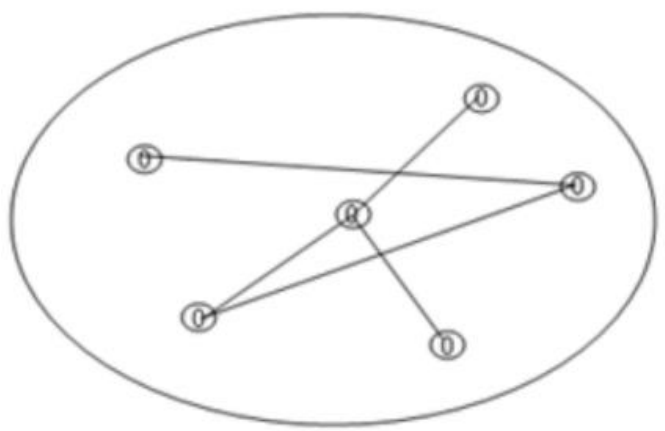

Gambar 11. Graph database

Berdasarkan Gambar 11. Graph database, merupakan desain Graph database. Pada Graph database terdapat node-node yang menghubungkan setiap data yang ada didalam database. masing-masing data dapat terhubung melalui node yang menghubung masing-masing database. 


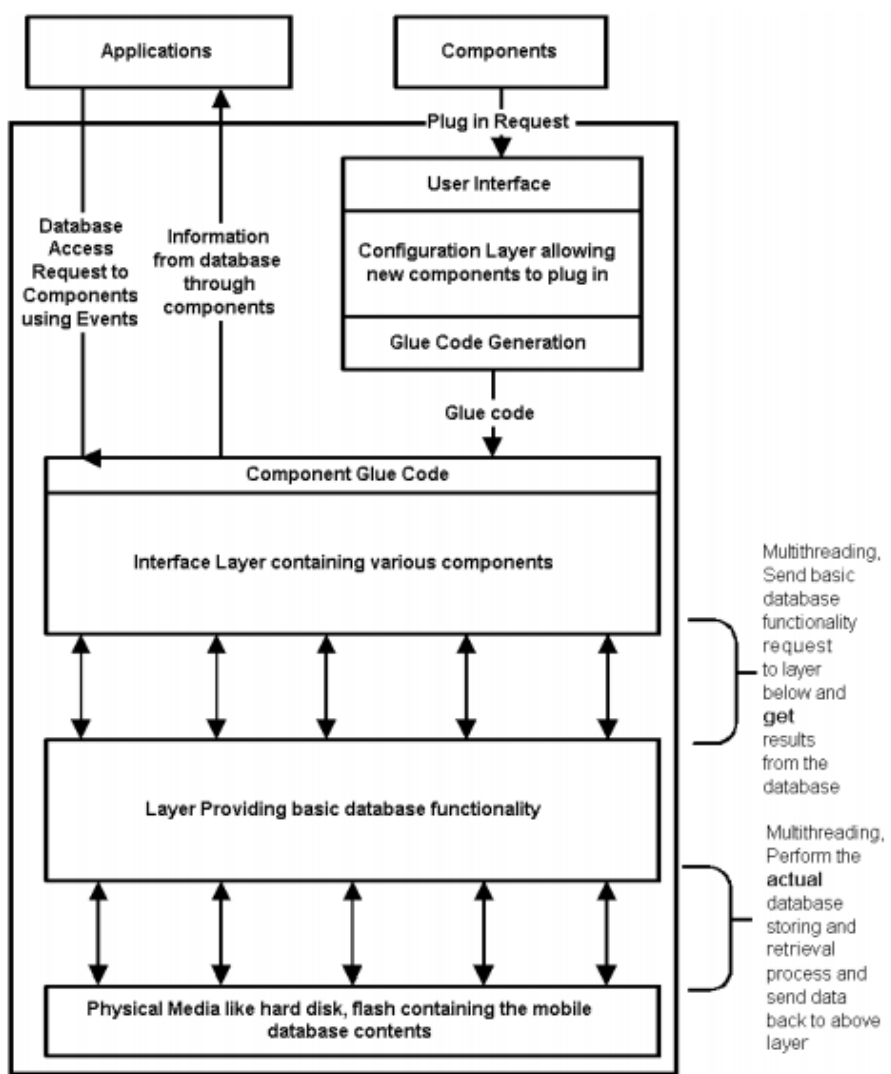

Gambar 12. Embedded database

Berdasarkan Gambar 12. Embedded database, merupakan contoh desain Embedded database. Pada database ini terdapat component yang dikirim ke user interface lalu masuk ke component glue code dan masuk ke layer providing, selanjutnya akan masuk ke database content yang memuat berbagai data dan ditampilkan melalui applications.

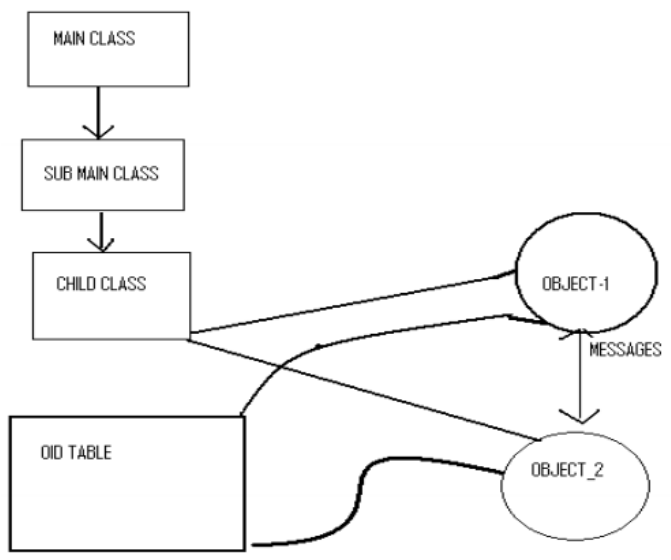

Gambar 13. Object-Oriented database

Berdasarkan Gambar 13. Object-Oriented database, merupakan contoh dari objectoriented database. Terdapat main class, sub-main-class, dan child-class. Pada child-cass terdapat dua object yaitu object-1 dan object-2, dimana kedua object tersebut dapat salng mengirim messages. 


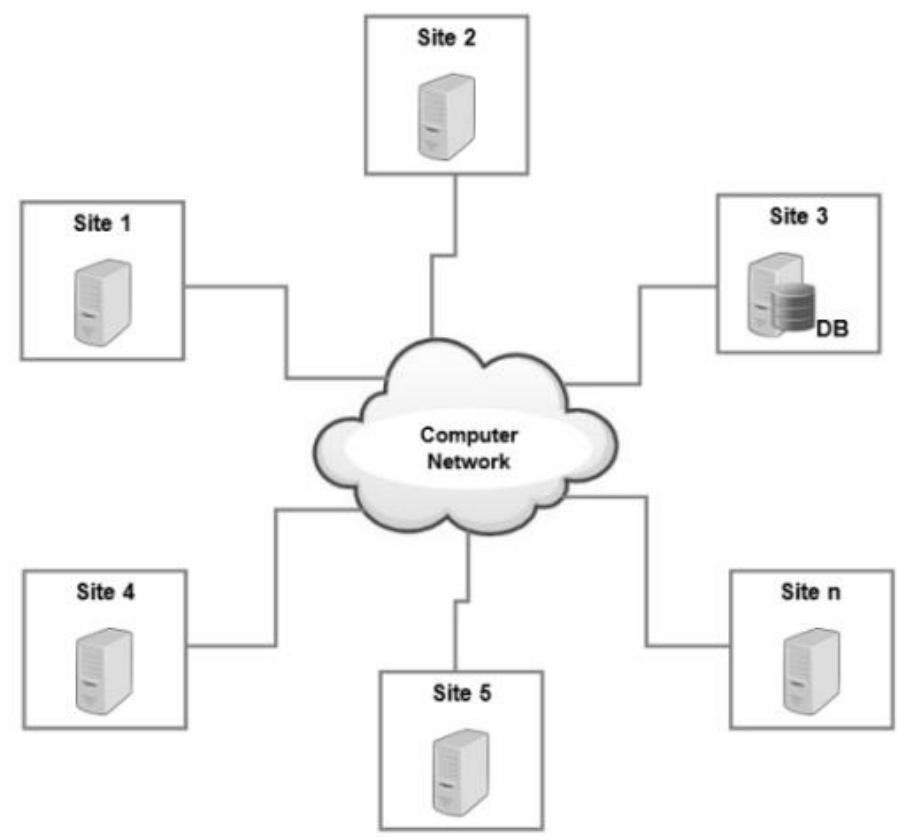

Gambar 14. Centralized database

Berdasarkan Gambar 14. Centralized database, merupakan contoh implementasi desain dari centralized database. Terdapat enam site berupa server-server yang terhubung dengan computer network. Terdapat satu site berupa server database yang digunakan sebagai pusat dari penyimpanan data pada centralized database.

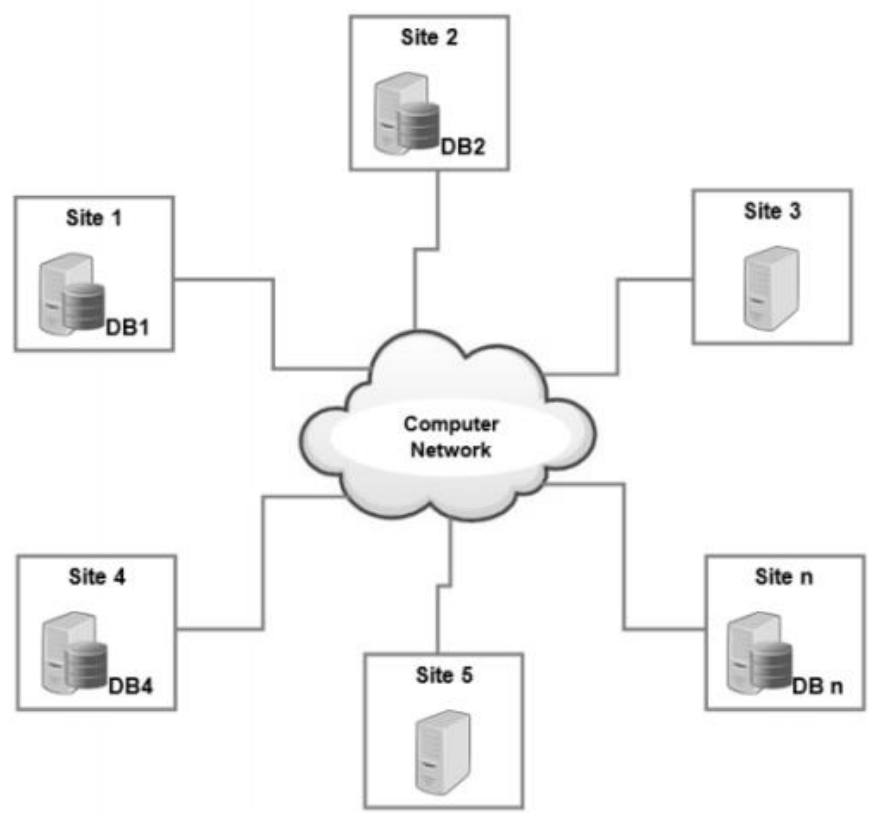

Gambar 15. Distributed database

Berdasarkan Gambar 15. Distributed database, merupakan contoh implementasi desain distributed database. Terdapat enam site berupa server-server yang terhubung dengan computer network. Terdapat empat server database yang berada di lokasi yang berbeda, ke-enam server database tersebut digunakan untuk menyimpan data. 


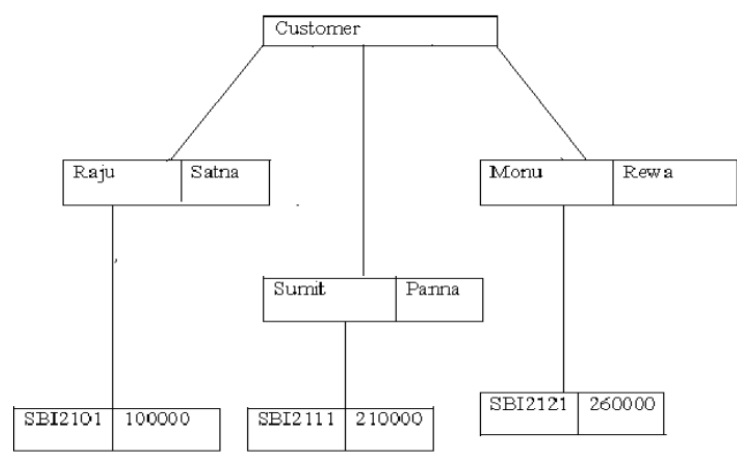

Gambar 16. Hierarchical database

Berdasarkan Gambar 16. Hierarchical database, merupakan contoh desain dari implementasi database hierarki. Terdapat beberapa field yang dihubungkan menggunakan hubungan parent-child dan digambarkan dalam struktur pohon. Customer sebagai parent mempunyai child berupa nama-nama customer yaitu Raju-Satria, Sumit-Parina, Manu-Rawa. Masing-masing dari nama customer mempunyai child lagi berupa nomor customer.

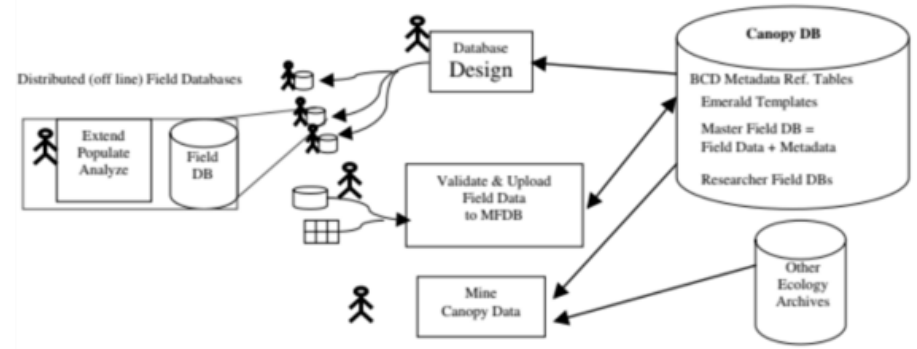

Gambar 17. End-user database

Berdasarkan Gambar 17. End-user database, merupakan contoh desain dari implementasi end-user database. Terdapat canopy $D B$ yang didalamnya terdapat proses researcher field $B D s$ dan lain sebagainya. Dari canopy $D B$ dapat dibuat desain database.

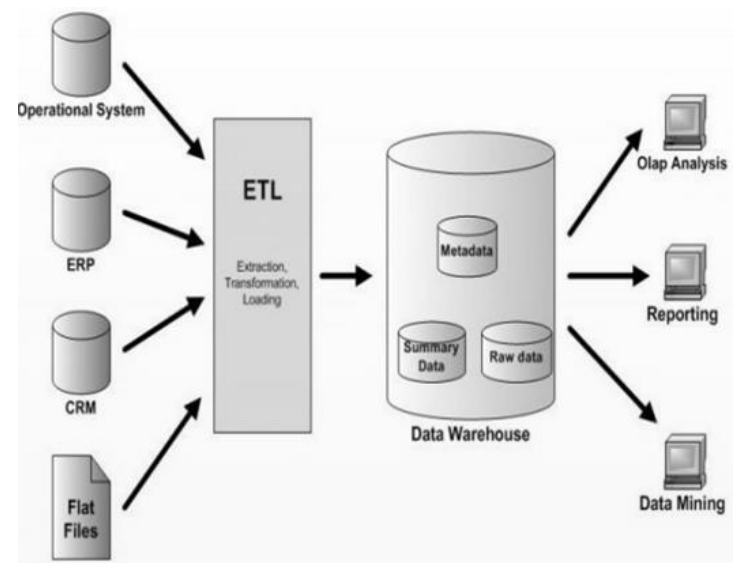

Gambar 18. Operational database.

Berdasarkan Gambar 18. Operational database, merupakan contoh desain dari implementasi operational database. Terdapat operational system, ERP, CRM, dan Flat Files yang dimasukkan ke dalam ETL, dan dari ETL akan dikirim ke data warehouse. Dari data warehouse akan menghasilkan olap analysis, reporting, dan data mining. 


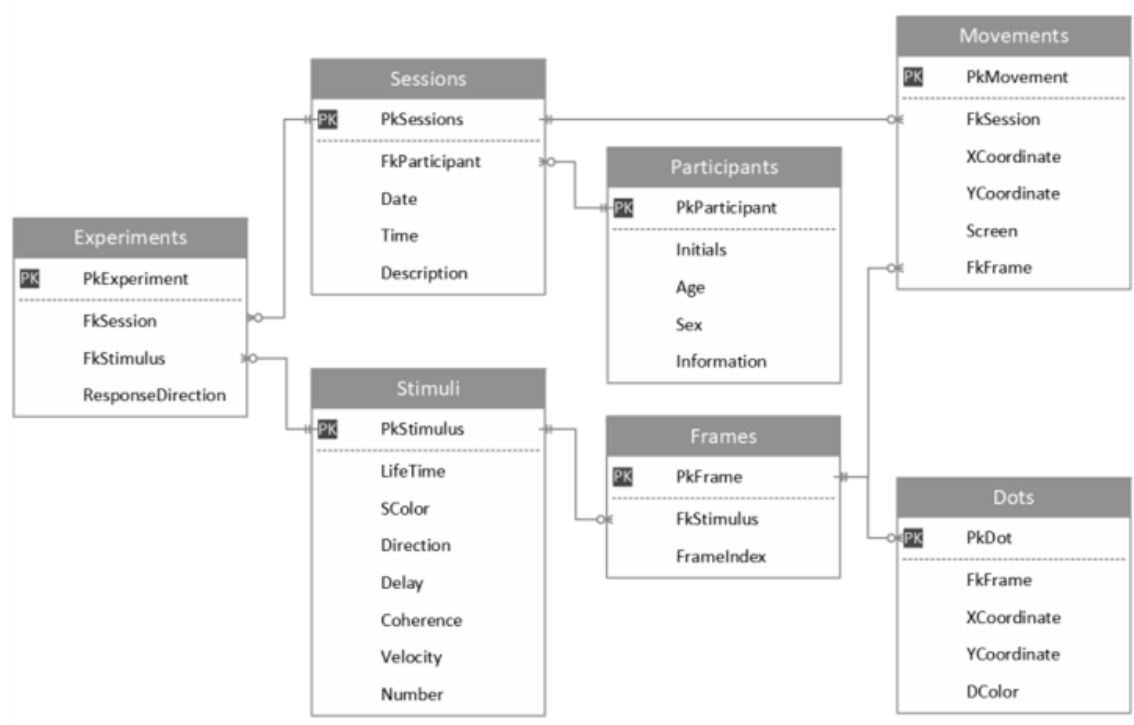

Gambar 19. Relational database

Berdasarkan Gambar 19. Relational database, merupakan contoh dari relational database. Terdapat tujuh tabel yaitu tabel experiment, stimuli, sessions, participants, frames, movements, dan dots. Masing-masing memiliki beberapa atribut yang termasuk didalamnya terdapat primary-key. Primary-key tersebut digunakan untuk menghubungkan antar tabel satu dengan yang lainnya.

Berdasarkan hasil data yang didapat dari beberapa referensi yang telah dianalisis, terdapat 12 jenis database yang terdiri dari Centralised database, Distributed database, Hierarchical database, End-user database, Operational database, Relational database, cloud database, Object-oriented database, Graph database, dan Embedded database.

\section{HASIL DAN PEMBAHASAN}

\section{Hasil Survei Teknik-Teknik Database Desain}

Teknik dalam desain database yang telah kami analisis dan kami temukan dari referensi berbagai jurnal. Kami mendapatkan tiga teknik sebagai sampel pengujian untuk mengetahui kecocokan antara teknik dan jenis database yang akan dipakai. Teknik yang kami jadikan sampel yaitu teknik normalisasi data, teknik date wilson, dan teknik entity-relationship. Sedangkan jenis database yang kami jadikan sampel yaitu model database relasional, database hierarki, dan database objek-oriented.

\section{Skenario Eksperimen dan Analisis terhadap Hasil Survei}

Skenario eksperimen dan analisis data dilakukan untuk mencocokkan teknik-teknik desain database dan jenis database. Tujuan yang akan dicapai dari eksperimen ini adalah untuk menjawab permasalah yang diajukan dalam paper survei ini. Skenario eksperimen yang dilakukan adalah sebagai berikut.

1. Skenario Pertama (Jawaban RQ5)

Membandingkan teknik-teknik desain database berdasarkan kekurangan, area implementasi, dan riwayat penelitiannya.

2. Skenario Kedua (Jawaban RQ6)

Mencocokkan teknik-teknik desain database dengan jenis database berdasarkan perbandingan yang telah dilakukan pada RQ5. 
3. Skenario Ketiga (Jawaban RQ7)

Menganalisa teknik-teknik dan jenis database yang sesuai dengan implementasi kasus perancangan database sistem informasi perpustakaan.

\section{Hasil Skenario Eksperimen Pertama (RQ5)}

Tabel 8. Perbandingan teknik-teknik desain database

\begin{tabular}{|c|c|c|c|c|c|}
\hline No. & $\begin{array}{l}\text { Teknik } \\
\text { Database } \\
\text { Design }\end{array}$ & $\begin{array}{l}\text { Area } \\
\text { Implemen } \\
\text { - tasi }\end{array}$ & Kekurangan & $\mathbf{S}$ & $\begin{array}{l}\text { Riwayat } \\
\text { Penelitian }\end{array}$ \\
\hline \multirow[t]{2}{*}{1.} & \multirow[t]{2}{*}{$\begin{array}{l}\text { Teknik } \\
\text { Normalisasi } \\
\text { Data }\end{array}$} & $\begin{array}{l}\text { Skala } \\
\text { besar }\end{array}$ & $\begin{array}{l}\text { Membutuhkan analisis } \\
\text { dan desain rinci pada } \\
\text { database yang akan } \\
\text { dibuat sehingga waktu } \\
\text { yang diperlukan dalam } \\
\text { mendesain database } \\
\text { menjadi lambat }\end{array}$ & \multirow[t]{2}{*}{$\begin{array}{l}{[7],} \\
{[8],} \\
{[9],} \\
{[10],} \\
{[11],} \\
{[12]}\end{array}$} & \multirow[t]{2}{*}{$\begin{array}{r}\text { - Indrajani } \\
(2015) \\
\text { - Gillenson } \\
(1987) \\
\text { - Maanari } \\
(2013)\end{array}$} \\
\hline & & Skala kecil & $\begin{array}{l}\text { Memperlambat peforma } \\
\text { database yang dibuat } \\
\text { dan diranjang karena } \\
\text { banyaknya tabel yang } \\
\text { harus diimplementasi }\end{array}$ & & \\
\hline \multirow[t]{2}{*}{2.} & \multirow[t]{2}{*}{$\begin{array}{l}\text { Teknik Date } \\
\text { Wilson }\end{array}$} & $\begin{array}{l}\text { Skala } \\
\text { besar }\end{array}$ & $\begin{array}{l}\text { Memungkinkan } \\
\text { terjadinya duplikasi data } \\
\text { serta kehilangan data } \\
\text { pada database }\end{array}$ & \multirow[t]{2}{*}{ [7] } & \multirow[t]{2}{*}{$\begin{array}{r}\text { - Gillenson } \\
\text { (1987) }\end{array}$} \\
\hline & & Skala kecil & $\begin{array}{l}\text { Diperlukan waktu yang } \\
\text { relatif lama untuk } \\
\text { menyelaraskan data yang } \\
\text { dibutuhkan dalam } \\
\text { pembuatan database }\end{array}$ & & \\
\hline \multirow[t]{2}{*}{3.} & \multirow[t]{2}{*}{$\begin{array}{l}\text { Teknik } \\
\text { entity- } \\
\text { Relationship }\end{array}$} & $\begin{array}{l}\text { Skala } \\
\text { besar }\end{array}$ & $\begin{array}{l}\text { Membutuhkan waktu } \\
\text { yang relatif lebih lama, } \\
\text { karena diperlukan } \\
\text { analisis yang cukup } \\
\text { detail dalam pembuatan } \\
\text { database }\end{array}$ & \multirow[t]{2}{*}{$\begin{array}{l}{[7],} \\
{[9],} \\
{[13],} \\
{[32]}\end{array}$} & \multirow[t]{2}{*}{$\begin{array}{r}\text { - Gillenson } \\
(1987) \\
\text { - Maanari } \\
(2013)\end{array}$} \\
\hline & & Skala kecil & $\begin{array}{l}\text { Membutuhkan media } \\
\text { penyimpanan yang lebih } \\
\text { besar untuk menyimpan } \\
\text { data pada database }\end{array}$ & & \\
\hline
\end{tabular}


Berdasarkan Tabel 8. Perbandingan teknik-teknik desain database, hasil skenario eksperimen pertama (RQ5) yaitu meembandingkan teknik-teknik mendesain database menghasilkan kekurangan teknik desain database pada area implementasi baik skala kecil maupun skala besar yang diambil dari referensi jurnal penelitian sebelumnya yang dianalisis.

\section{Hasil Skenario Eksperimen Kedua (RQ6)}

Tabel 9. Kombinasi Teknik Normalisasi Data dengan Jenis database

\begin{tabular}{|c|c|c|c|}
\hline $\begin{array}{l}\text { Teknik } \\
\mathbf{x} \\
\text { Desain }\end{array}$ & $\begin{array}{l}\text { Teknik Normalisasi } \\
\text { data x Database } \\
\text { Relasional }\end{array}$ & $\begin{array}{l}\text { Teknik Normalisasi } \\
\text { data x Database } \\
\text { Hierarki }\end{array}$ & $\begin{array}{l}\text { Teknik Normalisasi } \\
\text { data x Database } \\
\text { Object-oriented }\end{array}$ \\
\hline $\begin{array}{l}\text { Ke- } \\
\text { cocokan }\end{array}$ & Cocok & Cocok & Tidak cocok \\
\hline Ket & $\begin{array}{lr}\text { Karena } & \text { teknik } \\
\text { normalisasi } & \text { data dan } \\
\text { database } & \text { relasional } \\
\text { mempunyai } & \text { kemiripan } \\
\text { aspek-aspek } & \text { yang } \\
\text { dibutuhkan } & \text { untuk } \\
\text { membuat } & \text { suatu } \\
\text { database yang baik } \\
\text { sehingga } & \text { teknik } \\
\text { normalisasi data cocok } \\
\text { digunakan } & \text { dalam } \\
\text { mendesain } & \text { database } \\
\text { relasional. } & \end{array}$ & $\begin{array}{lr}\text { Karena } & \text { teknik } \\
\text { normalisasi data yang } \\
\text { digunakan untuk } \\
\text { membuat database } \\
\text { hierarki membutuhkan } \\
\text { tahap normalisasi data } \\
\text { hingga tahap } 3 \mathrm{NF} \\
\text { sudah cukup untuk } \\
\text { membuat struktur } \\
\text { database yang baik } \\
\text { dan mudah dikelola. }\end{array}$ & 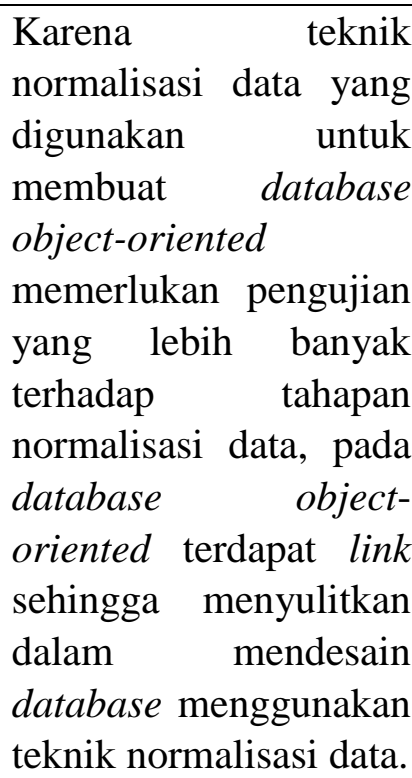 \\
\hline$S$ & \multicolumn{3}{|c|}{ [7], [8], [9], [10], [11], [12] } \\
\hline
\end{tabular}

Berdasarkan Tabel 9. Kombinasi Teknik Normalisasi Data dengan Jenis database, hasil skenario eksperimen kedua (RQ6) yaitu mengkombinasikan teknik normalisasi data dengan beberapa jenis database diantaranya database relasional, hierarki dan object-oriented. Hasil analisis menghasilkan kecocokan antara teknik normalisasi data dengan jenis database yang dikombinasikan beserta dengan keterangan masing-masing hasil dari kombinasi antara teknik normalisasi data dengan jenis database.

Tabel 10. Kombinasi Teknik Date Wilson dengan Jenis database

\begin{tabular}{|l|l|c|l|}
\hline $\begin{array}{l}\text { Teknik } \\
\text { Desain }\end{array}$ & $\begin{array}{l}\text { Teknik Date Wilson } \\
\mathbf{x} \text { Database } \\
\text { Relasional }\end{array}$ & $\begin{array}{l}\text { Teknik Date Wilson } \mathbf{x} \\
\text { Database Hierarki }\end{array}$ & $\begin{array}{l}\text { Teknik Date Wilson } \mathbf{x} \\
\text { Database Objek- } \\
\text { oriented }\end{array}$ \\
\hline $\begin{array}{l}\text { Ke- } \\
\text { cocokan }\end{array}$ & Cocok & Cocok & Tidak cocok \\
\hline
\end{tabular}




\begin{tabular}{|c|c|c|c|}
\hline Ket & $\begin{array}{l}\text { Karena teknik date } \\
\text { wilson yang } \\
\text { digunakan untuk } \\
\text { mendesain database } \\
\text { relasional mempunyai } \\
\text { tahapan yang sesuai } \\
\text { dengan jenis database } \\
\text { relasional dalam } \\
\text { membuat database } \\
\text { sehingga teknik date } \\
\text { wilson cocok untuk } \\
\text { mendesain database } \\
\text { relasional. }\end{array}$ & $\begin{array}{l}\text { Karena teknik date } \\
\text { wilson yang digunakan } \\
\text { dalam mendesain } \\
\text { database hierarki } \\
\text { sesuai dengan tahapan } \\
\text { dalam } r \text { membuat } \\
\text { database hierarki. } \\
\text { Oleh karena itu, teknik } \\
\text { date wilson cocok } \\
\text { digunakan } \\
\text { mendesain database } \\
\text { hierarki. }\end{array}$ & $\begin{array}{l}\text { Karena teknik date } \\
\text { wilson yang digunakan } \\
\text { dalam mendesain } \\
\text { database object oriented } \\
\text { mempunyai tahapan } \\
\text { yang rumit untuk } \\
\text { menghubungkan satu } \\
\text { data dengan data lainnya } \\
\text { yang dikarenakan } \\
\text { terdapatnya pointer atau } \\
\text { link yang ada pada } \\
\text { database object- } \\
\text { oriented. }\end{array}$ \\
\hline$S$ & [7] & & \\
\hline
\end{tabular}

Berdasarkan Tabel 10. Kombinasi Teknik Date Wilson dengan Jenis database, hasil skenario eksperimen kedua (RQ6) yaitu mengkombinasikan teknik date wilson dengan beberapa jenis database diantaranya database relasional, hierarki dan object-oriented. Hasil analisis menghasilkan kecocokan antara teknik date wilson dengan jenis database yang dikombinasikan beserta dengan keterangan masing-masing hasil dari kombinasi antara teknik date wilson dengan jenis database.

Tabel 11. Kombinasi Teknik entity-relationship dengan Jenis database

\begin{tabular}{|c|c|c|c|}
\hline $\begin{array}{l}\text { Teknik } \\
\mathbf{x} \\
\text { Desain }\end{array}$ & $\begin{array}{l}\text { Teknik Entity- } \\
\text { Relationship } \mathrm{x} \\
\text { Database Relasional }\end{array}$ & $\begin{array}{l}\text { Teknik Entity- } \\
\text { Relationship } \mathrm{x} \\
\text { Database Hierarki }\end{array}$ & $\begin{array}{l}\text { Teknik Entity- } \\
\text { Relationship } x \text { Database } \\
\text { Object-oriented }\end{array}$ \\
\hline $\begin{array}{l}\mathrm{Ke}- \\
\text { cocokan }\end{array}$ & Cocok & Cocok & Cocok \\
\hline Ket. & $\begin{array}{l}\text { Karena teknik entity- } \\
\text { relationship yang } \\
\text { digunakan untuk } \\
\text { membuat database } \\
\text { relasional } \\
\text { mempunyai tahapan } \\
\text { dan aspek yang sama } \\
\text { untuk membuat } \\
\text { database relasional. }\end{array}$ & $\begin{array}{l}\text { Karena teknik entity- } \\
\text { relationship yang } \\
\text { digunakan untuk } \\
\text { membuat database } \\
\text { hierarki mempunyai } \\
\text { struktur yang sama } \\
\text { dalam menghubungkan } \\
\text { entitas parent dan child } \\
\text { yang ada pada } \\
\text { database. }\end{array}$ & $\begin{array}{l}\text { Karena teknik entity- } \\
\text { relationship yang } \\
\text { digunakan dalam object- } \\
\text { oriented database dapat } \\
\text { menghubungkan antar } \\
\text { entitas yang berupa } \\
\text { object serta entitas antara } \\
\text { object dengan properti } \\
\text { pendukungnya. }\end{array}$ \\
\hline$S$ & \multicolumn{3}{|l|}{ [7], [9], [13], [32] } \\
\hline
\end{tabular}


Berdasarkan Tabel 11. Kombinasi Teknik entity-relationship dengan Jenis database, hasil skenario eksperimen kedua (RQ6) yaitu mengkombinasikan teknik entity-relationship dengan beberapa jenis database diantaranya database relasional, hierarki dan object-oriented. Hasil analisis menghasilkan kecocokan antara teknik entity-relationship dengan jenis database yang dikombinasikan beserta dengan keterangan masing-masing hasil dari kombinasi antara teknik entity-relationship dengan jenis database.

\section{Hasil Skenario Eksperimen Ketiga (RQ7)}

Dalam skenario eksperimen ini, terdapat satu sampel berupa kasus sistem informasi perpustakaan. Analisis terhadap kasus ini menghasilkan arsitektur database yang menggabungkan teknik entity-relationship dengan jenis database relasional.

Yang pertama kali dilakukan dalam perancangan database ini yaitu mengumpulkan data yang diperlukan. Setelah data terkumpul maka data akan dikelompokkan menjadi tabel berdasarkan kriteria yang sama. Setelah data dikelompokkan, selanjutnya adalah pemberian primary key dan foreign key lalu antar tabel yang memiliki koneksi dihubungkan menggunakan teknik entity-relationship sehingga seluruh data saling terhubung melalui relasi, hasil dari rancangan database tersebut dapat dilihat pada gambar berikut.

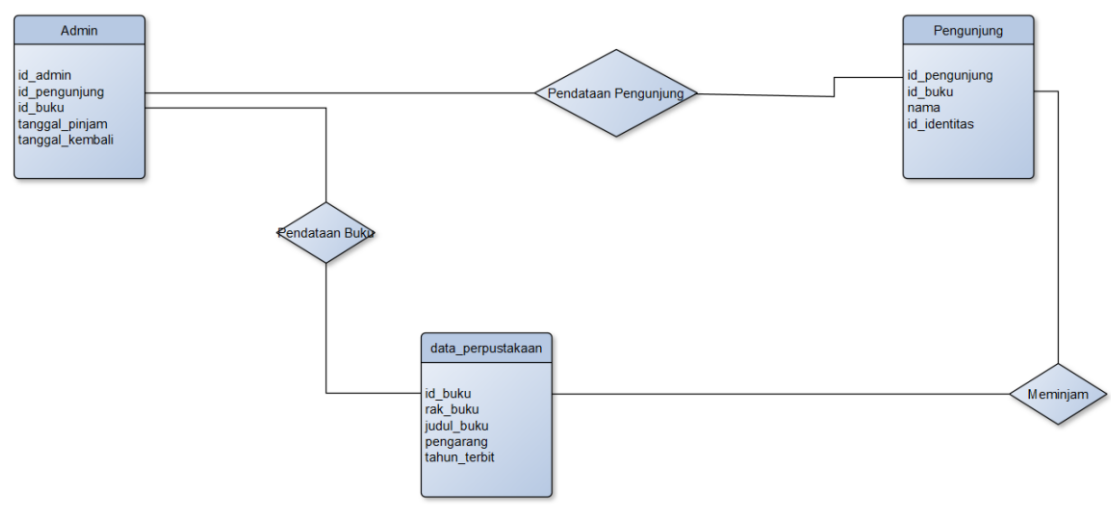

Gambar 20. Struktur database sistem informasi perpustakaan

Pada Gambar 20. Struktur database sistem informasi perpustakaan, diketahui terdapat tabel $a d m i n$, tabel pengunjung, dan tabel data perpustakaan. Tabel admin dapat melakukan aksi berupa pendataan pengunjung, tabel pengunjung dapat melakukan aksi berupa meminjam dan tabel admin dapat melakukan aksi berupa pendataan buku.

\section{KESIMPULAN}

Desain database merupakan merupakan bagian paling penting dalam membuat sebuah database. Desain database merupakan bidang yang akan selalu berkembang dari waktu ke waktu. Survei ini bertujuan untuk memberikan analisis komprehensif terhadap teknik-teknik database desain dari segi manfaat, kekurangannya, dan riwayat penelitiannya. Metode yang digunakan adalah Systematic Literature Review terhadap total 19 sumber jurnal signifikan dan 35 paper penelitian yang membahas tentang teknik-teknik database desain dari tahun 1987 sampai 2018. Survei ini menghasilkan tiga teknik database design diantaranya teknik normalisasi data, teknik date wilson, dan teknik entity-relationship. Dari hasil analisis terhadap tiga teknik tersebut dapat ditarik kesimpulan sebagai berikut:

1. Teknik yang paling banyak digunakan dalam penelitian (1987-2018) adalah teknik entityrelational dan teknik normalisasi data. 
2. Teknik yang memiliki kecocokan terhadap banyak database dilihat dari area implementasi dan kecocokannya adalah teknik entity-relationship

Selain itu, proses dari analisis ini juga menghasilkan teknik desain database yang cocok digunakan pada kasus perancangan database sistem informasi perpustakaan. Teknik yang cocok yang digunakan dalam mendesain database sistem informasi perpustakaan yaitu teknik entityrelationalship dengan menggunakan jenis database relasional.

\section{REFERENSI}

[1] W. Ali, M. U. Shafique, M. A. Majeed, and A. Raza, "Comparison between SQL and NoSQL Databases and Their Relationship with Big Data Analytics,” Asian J. Res. Comput. Sci., vol. 4, no. 2, pp. 1-10, 2019, doi: 10.9734/ajrcos/2019/v4i230108.

[2] S. Khotijah, "DESAIN DATABASE SISTEM INFORMASI AKADEMIK PADA Program Studi Teknik Informatika Fakultas Teknik , Matematika dan Ilmu Pengetahuan Alam Universitas Indraprasta PGRI," Jogiyanto -Desain Database Sist. Inf., vol. 9, no. 2, pp. 154-165, 2016.

[3] S. S. Wibagso and E. Lia, "Desain Model Database Layanan Panti Werdha dengan Menerapkan Metode Database Life Cycle," J. Tek. Inform. dan Sist. Inf., vol. 6, no. 3, pp. 573-588, 2020, doi: 10.28932/jutisi.v6i3.3047.

[4] N. Hidayati, "Modul Sistem Basis Data," Univ. Bina Sarana Inform., no. Pontianak: AMIK BSI Pontianak, pp. 1-7, 2012, [Online]. Available: https://repository.bsi.ac.id/index.php/unduh/item/271361/Modul-SistemBasisData-1.pdf.

[5] V. C. Storey and R. C. Goldstein, "Knowledge-Based Design Introduction," vol. 17, no. 1, pp. 25-46, 2014.

[6] B. Kitchenham and S. Charters, "Guidelines for performing Systematic Literature Reviews in SE," Guidel. Perform. Syst. Lit. Rev. SE, pp. 1-44, 2007, [Online]. Available: https://userpages.unikoblenz.de/\%7B \%7Dlaemmel/esecourse/slides/slr.pdf.

[7] M. L. Gillenson, "The duality of database structures and design techniques," Commun. ACM, vol. 30, no. 12, pp. 1056-1065, 1987, doi: 10.1145/33447.33451.

[8] Indrajani, “Database Design.” PT Elex Media Komputindo, Jakarta, 2015.

[9] J. I. Maanari, R. Sengkey, I. H. F. Wowor, M. Kom, and Y. D. Y. Rindengan, "Perancangan Basis Data Perusahaan Distribusi Dengan Menggunakan Oracle,” J. Tek. Elektro dan Komput., vol. 2, no. 2, 2013, doi: 10.35793/jtek.2.2.2013.1719.

[10] Z. Efendy, "Normalisasi Dalam Desain Database," J. CorelIT, vol. 4, no. 1, pp. 34-43, 2018.

[11] T. Li, J. Xiao, Z. Sun, and X. Bian, "Normalization of class hierarchy in databases," J. Comput. Sci. Technol., vol. 11, no. 4, pp. 356-364, 1996, doi: 10.1007/bf02948479.

[12] S. Suryadi, "Implementasi Normalisasi Dalam Perancangan Database Relational," U-NET J. Tek. Inform., vol. 3, no. 2, pp. 20-26, 2019, doi: 10.52332/u-net.v3i2.7.

[13] I.-Y. Song, M. Evans, and E. K. Park, "A Comparative Analysis of Entity-Relationship Diagrams," J. Comput. Softw. Eng., vol. 3, no. 4, pp. 427-459, 1995.

[14] D. G. Chandra, "A Survei on Cloud Database," 2013.

[15] W. Al Shehri, "Cloud Database Database as a Service," Int. J. Database Manag. Syst., vol. 5, no. 2, pp. 1-12, 2013, doi: 10.5121/ijdms.2013.5201.

[16] M. Alam and K. A. Shakil, "Cloud Database Management System Architecture Object-Oriented Database," UACEE Int. J. Comput. Sci. its Appl., vol. 3, no. 1, pp. 978-981, 2013.

[17] M. Dave, "International Journal of Advanced Research in SQL and NoSQL Databases," Int. J. Adv. Res. Comput. Sci. Softw. Eng. Res., vol. II, no. 8, 2016.

[18] M. Saxena, Z. Ali, and V. K. Singh, "NoSQL Databases- Analysis , Techniques, and Classification," no. July 2014, 2015.

[19] N. Jatana, S. Puri, M. Ahuja, I. Kathuria, and D. Gosain, “A Survei and Comparison of Relational and Non-Relational Database,” Int. J. Eng. Res. Technol., vol. 1, no. 6, pp. 1-5, 2012.

[20] R. Angles and C. Gutierrez, "Survei of graph database models," ACM Comput. Surv., vol. 40, no. 1, pp. 1-39, 2008, doi: 10.1145/1322432.1322433.

[21] Y. Y. Sahria and D. H. Fudholi, "Pemodelan Pengetahuan Graph Database Untuk Jejaring Penelitian Kesehatan di Indonesia," J. Media Inform. Budidarma, vol. 4, no. 3, p. 604, 2020, doi: 10.30865/mib.v4i3.2183.

[22] S. I. Ahamed and S. Vallecha, "Component-based embedded database for mobile embedded systems," Int. Conf. Inf. Technol. Coding Comput. ITCC, vol. 1, pp. 534-538, 2004, doi: 10.1109/ITCC.2004.1286512. 
[23] W. Kim, “Object-Oriented Databases: Definition and Research Directions," IEEE Trans. Knowl. Data Eng., vol. 2, no. 3, pp. 327-341, 1990, doi: 10.1109/69.60796.

[24] P. K. Rai, "Studies and Analysis of Popular Database Models," Lp, vol. 4, no. 5, pp. 834-838, 2015.

[25] R. Unland and G. Schlageter, "Object-oriented database systems: Concepts and perspectives," Lect. Notes Comput. Sci. (including Subser. Lect. Notes Artif. Intell. Lect. Notes Bioinformatics), vol. 466 LNCS, pp. 154-197, 1990, doi: 10.1007/3-540-53397-4_36.

[26] K. K. Ezéchiel, S. Kant, and R. Agarwal, "A systematic review on distributed databases systems and their techniques,” J. Theor. Appl. Inf. Technol., vol. 97, no. 1, pp. 236-266, 2019.

[27] A. Mohammed and B. M. Saleh, "Centralized Database: A Prerequisite for Security and Sustainable Development in Nigeria,” Int. J. Innov. Res. Comput. Sci. Technol., vol. 5, no. 1, pp. 209-213, 2017, doi: 10.21276/ijircst.2017.5.1.7.

[28] J. B. Cushing et al., "Component-based end-user database design for ecologists," J. Intell. Inf. Syst., vol. 29, no. 1, pp. 7-24, 2007, doi: 10.1007/s10844-006-0028-6.

[29] T. Jalaja and M. Shailaja, "A Comparative Study on Operational Database, Data Warehouse and Hadoop File System,” Int. J. Eng. Tech. -Volume I Issue, vol. 5, no. 5, pp. 37-41, 2015, [Online]. Available: http://www.ijetjournal.org.

[30] R. Kraleva, V. Kralev, N. Sinyagina, P. Koprinkova-Hristova, and N. Bocheva, "Design and analysis of a relational database for behavioral experiments data processing," Int. J. Online Eng., vol. 14, no. 2, pp. 117-132, 2018, doi: 10.3991/ijoe.v14i02.7988.

[31] A. Meier and M. Kaufmann, SQL \& NoSQL Databases: Models, Languages, Consistency Options and Architectures for Big Data Management. 2019.

[32] P. Shoval and S. Shiran, "Entity-relationship and object-oriented data modeling - An experimental comparison of design quality," Data Knowl. Eng., vol. 21, no. 3, pp. 297-315, 1997, doi: 10.1016/S0169023X(97)88935-5. 